\title{
Knowledge Sharing Behavior of Rice Farmers in the Cyber-Villages
}

\author{
Ludito V. Ramirez ${ }^{1}$ and Ma. Theresa H. Velasco ${ }^{2}$ \\ ${ }^{1}$ Naval State University, Naval, Biliran, Philippines \\ ${ }^{2}$ University of the Philippines Los Baños, College, Laguna, Philppines
}

\begin{abstract}
The International Rice Research Institute (IRRI) has established cyber-villages in an effort to speed up dissemination and adoption of rice technologies. How farmers share information obtained from the sources is less documented. In this paper, we present an analysis of the knowledge sharing behavior of rice farmers in the Cyber-villages -- the communities assisted by IRRI for its innovative technology transfer modalities in Infanta, Quezon. The study involved 76 rice farmers from three LGU- and three NGO-managed barangays. Results revealed that both LGU-managed and NGO-managed cyber-village farmers had highly positive knowledge seeking behavior and moderately positive knowledge donating behavior. It indicated that they were more of knowledge seekers than knowledge donors. The latent networks are predominantly star and linear chain, characterized by sparse central hubs and non-reciprocated ties. The central actors are limited to the intermediaries, farmer-leaders, and emerging farmer-consultants.
\end{abstract}

Keywords: Knowledge sharing ties, knowledge donating, knowledge seeking; rice information transfer, social network analysis

\section{INTRODUCTION}

Knowledge sharing is the process where individuals mutually exchange their knowledge - both tacit and explicit knowledge - and jointly create new knowledge (Van den Hooff \& De Ridder, 2004; De Vries et al., 2006). This implies that every knowledge sharing behavior consists of both bringing (or donating) and getting (or collecting) knowledge. Following Van den Hooff and De Ridder (2004) and De Vries et al. (2006) label the two central behaviors as follows: (a) knowledge donating, communicating one's personal intellectual capital to others; and (b) knowledge seeking, consulting others to get them to share their intellectual capital. Knowledge sharing also refers to knowledge exchange. It is conceptualized as the transfer of knowledge by interaction between different parties through linkage and exchange which can result in mutual learning (Kuhne et al., 2006).

In most of the research conducted, knowledge sharing is quantified and the Likerttype scale is commonly used to measure this variable. In their studies, De Vries et al. (2006) and Van den Hooff and Huysman (2009) presented the knowledge sharing measures to include the knowledge donating and knowledge seeking statements. However, Galie et al. (2009) used stories and narratives in analyzing knowledge sharing.

Recent studies on knowledge sharing behaviors focused on the individuals within corporate organizations (De Vries et al., 2006; Van den Hooff \& Huysman, 2009; Aliei et al., 2011; Heyradi et al., 2011), professional organizations (Galie et al., 2009), and virtual enterprises (Liu et al., 2011). Few research on knowledge sharing among smallholder 
farmers and informal community organizations have been conducted. Wang and Noe (2010) identified some emerging issues and future research directions in knowledge sharing research. Among the issues is understanding differences between interpersonal and technology-aided knowledge sharing.

The International Rice Research Institute (IRRI), an international research and development organization based at Los Banos, Laguna, Philippines, has designed in 2011 technology transfer modalities to strengthen farmers' learning and used the technology transfer modalities to address the problem of food security worldwide (Lapitan, 2012). In the Philippines, IRRI is implementing the Cyber-Village Project which aims to enhance rice farmers' productivity by improving their access to and application of rice and other related knowledge through the use of alternative models of technology transfer combined with relevant information-communication technology (ICT). One of the pilot project sites is the municipality of Infanta, Quezon Province. The technology transfer modalities were downloaded through the Cyber-Village Project. Under the Cyber-Village Project, IRRI provided technical experts, ICT infrastructure, and capability building services to the lead implementers - LGU of Infanta, Quezon through its Municipal Agriculturist's Office (MAO) and a non-government organization (NGO), the Infanta Integrated Community Development Assistance, Inc. (ICDAI). The lead agencies facilitated in the diffusion of new rice technology from IRRI to the rice farmers in the villages. In the process of technology diffusion, documentation and assessment of the knowledge exchange process among the rice farmers is important in the design of technology since it has direct bearing on its effectiveness (Reason, 1990; Monahan, 2000; and Triantaphyllou, 2000). It will also inform the implementing agency on whether or not the same technologies or information from the source are reaching the intended users. Since there is no documentation yet on the interpersonal and technology-mediated knowledge sharing of the farmers in the pilot cyber-villages of IRRI, a case study was conducted. The study also tried to compare the knowledge sharing and donating behavior of the farmers in the LGU- and NGO-managed villages.

This paper looked into the transfer of information in the context of rice farming at the cyber-villages. The question posed was: from whom do rice farmers seek relevant information and to whom do they share the information? Aside from the Likert-type scale in measuring knowledge sharing behavior, this study analyzed the knowledge sharing ties of the rice farmers using the social network analysis.

\section{METHODOLOGY}

Research Design. The study followed the descriptive research design. Guided by the case study as a form of descriptive research, the study tried to examine who share and from whom farmers seek information within the Cyber-Village Project of IRRI.

Locale of the Study. Infanta, one of the oldest towns in the province of Quezon, Philippines, is a first class municipality. As of December 2010, it had a population of 64,866 people in 15,151 families from its 36 barangays. It is situated in the northern part of the province lying along the coast of the Pacific Ocean facing the island towns of Polillo. Located 144 kilometers northeast of Manila, and 136 kilometers north of Lucena City, Infanta is also known as the "gateway to the Pacific" (Figure 1). According to the livelihood report of the 1995 Census, $45 \%$ of the working population was engaged in agriculture (primarily rice farming) and fishery while another $41 \%$ was engaged in trade and services. Others $(14 \%)$ were engaged in quarrying, manufacturing, construction and utilities. Considered as the largest lambanog manufacturer in the province of Quezon, Infanta is the center of economic activity in the northern part of the province. The Agri-Profile Report of the Municipal Agriculturist's Office of Infanta, Quezon (2011) recounted that the town has 1,836 hectares of irrigated rice farms cultivated by 2,948 farmers. Production posted at 4.15 and 4.30 tons per hectare during wet and dry seasons, respectively. 


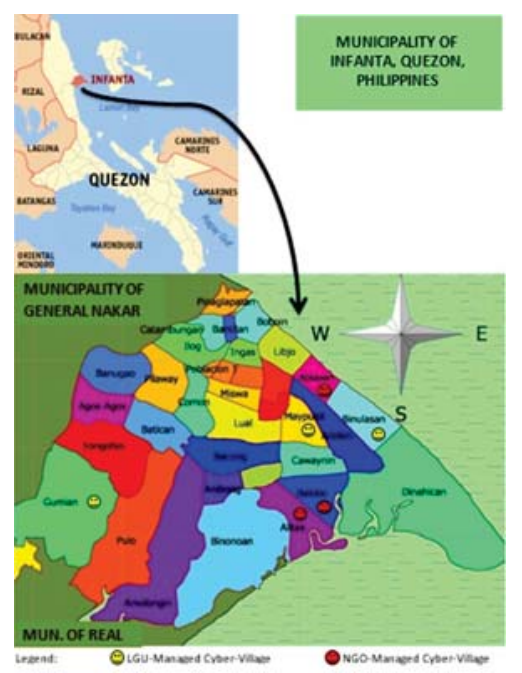

Figure 1. Map of Infanta, Quezon Showing the cybe-villages (MAO, Infanta, Quezon).

The municipality of Infanta in Quezon Province was chosen as study site since IRRI was implementing the Cyber-Village Project within the said town. Out of 36 barangays of Infanta, six barangays were covered by the Cyber-Village Project of IRRI. The LGUmanaged barangays included Binulasan, Gumian, and Maypulot while the NGO-managed barangays included Abiawin, Alitas, and Balobo.

Respondents and Sampling. Judgment sampling technique was used and respondents were selected following these criteria: 1) the respondent had been involved in any of the activities implemented by the NGO and LGU relative to the Cyber-Village Project of IRRI, and 2) the respondent was available and willing to participate during the time of the study. In selecting the rice farmer respondents, the intermediary (who happened to be the agricultural technicians designated by LGU and community worker designated by the NGO) were consulted. The respondents included 35 rice farmers from the LGU-managed and 41 rice farmers from the NGO-managed cyber-villages. The farmer-respondents were tapped during the survey, while the intermediaries were considered as key informants.

Measurement of Variables. To measure the knowledge sharing behaviors, a Likert-type scale was developed (Table 1) adopting the measures and categorization used by De Vries et al. (2006) and Van Den Hooff and Huysman (2009).

The context used in this study was knowledge sharing of new rice information or technology among the farmers in the cyber-villages. The farmers were asked to indicate whether they strongly agreed, agreed, were neutral, disagreed, or strongly disagreed (rated as $5,4,3,2$, or 1, respectively) to each of the statements. As used by De Vries et al. (2006) and Van Den Hooff and Huysman (2009), the mean scores were derived and interpreted as: highly positive $(M=4.20-5.00)$, moderately positive $(M=3.40-4.19)$, neutral $(M=2.60-3.39)$, moderately negative $(\mathrm{M}=1.80-2.59)$, and highly negative (1.00-1.79).

During the sociometric survey, the following questions were asked to the farmers: (for knowledge seeking ties) if you want to know about new rice information or technology, from whom among the cyber-village participants do you talk to?; and (for knowledge donating ties) if you want to share the new information or technology, to whom among the cyber-village participants do you share it with? To analyze and generate the knowledge sharing maps, the UCINET 6 software was used for the social network analysis.

\section{RESULTS AND DISCUSSION}

Except for sex, the rice farmers from both camps basically had similar profile 
characteristics. More female rice farmers were actively involved in the NGO-managed cyber-villages. In terms of age, they belonged to old category (average of 49-52 years). They were mostly married and obtained high school education. They had average household size of 5 members (Table 2).

Table 1. Measures of the knowledge sharing behaviors of farmers De Vries et al. (2006) and Van Den Hooff and Huysman (2009).

\begin{tabular}{ll}
\hline VARIABLE & QUESTION \\
\hline
\end{tabular}

Knowledge seeking

Knowledge donating
1. When I need certain new rice information or technology, I ask from anybody who knows about it.

2. I like to be informed of what my co-farmers know about the new rice information/technology.

3. I ask from anyone about their practices when I need to learn about new rice information or technology.

4. When somebody is good at new information or technology in rice farming, I ask them to teach me how to do it.

1. When I've learned something new about rice farming (information, technology), I tell my co-farmers.

2. I share the information I have with my co-farmers.

3. I think it is important that my co-farmers know what I am doing in the rice farm.

4. I regularly tell my co-farmers what I am doing in the rice farm.

Table 2. Profile summary of the farmers in the LGU- and NGO-managed cyber-villagers.

\begin{tabular}{|c|c|c|}
\hline VARIABLE & LGU-MANAGED & NGO-MANAGED \\
\hline Age & $\begin{array}{l}\text { Old Category } \\
\text { (Average }=52 \text { yrs.) }\end{array}$ & $\begin{array}{l}\text { Old category } \\
\text { (Average }=49 \text { yrs.) }\end{array}$ \\
\hline Sex & $\begin{array}{l}\text { Mostly Male } \\
(60 \%)\end{array}$ & $\begin{array}{l}\text { Mostly Female } \\
(56.1 \%)\end{array}$ \\
\hline Civil Status & $\begin{array}{l}\text { Mostly Married } \\
\left(77.2^{\circ} \%\right)\end{array}$ & $\begin{array}{l}\text { Mostly Married } \\
(85.4 \%)\end{array}$ \\
\hline Highest Education & Mostly High School & Mostly High School \\
\hline Household Size & Average $=5$ & Average $=4.4$ \\
\hline
\end{tabular}

\section{Knowledge Sharing Behaviors}

Results revealed that both LGU-managed and NGO-managed cyber-village farmers had highly positive knowledge seeking behavior and moderately positive knowledge donating behavior. It indicated that they were more of knowledge seekers than knowledge donors.

Knowledge Seeking Behavior. Both the LGU-managed and NGO-managed cybervillagers were highly positive ( $\mathrm{M}=4.26$ and $\mathrm{M}=4.29$, respectively) on the statement, "When I need certain new rice information/technology, I ask from anybody who knows about it" (Table 3). 
Table 3. Knowledge seeking behavior of the rice farmers in the cyber-villages.

\begin{tabular}{lccccc}
\hline \multicolumn{1}{c}{ MEASURE } & \multicolumn{2}{c}{ LGU-MANAGED } & \multicolumn{2}{c}{ NGO-MANAGED } \\
\cline { 2 - 6 } & $\begin{array}{l}\text { Mean } \\
\text { Score }\end{array}$ & $\begin{array}{c}\text { Qualitative } \\
\text { Description of } \\
\text { Behavior }\end{array}$ & $\begin{array}{c}\text { Mean } \\
\text { Score }\end{array}$ & $\begin{array}{c}\text { Qualitative } \\
\text { Description of } \\
\text { Behavior }\end{array}$ \\
\hline $\begin{array}{l}\text { When I need certain new rice } \\
\text { information/technology, I ask } \\
\text { from anybody who knows about it. }\end{array}$ & 4.26 & Highly Positive & 4.29 & Highly Positive \\
$\begin{array}{l}\text { I like to be informed of what my } \\
\text { co-farmers know about the new } \\
\text { rice information/technology. }\end{array}$ & 4.23 & Highly Positive & 4.27 & Highly Positive \\
$\begin{array}{l}\text { I ask from anyone about their } \\
\text { practices when I need to learn } \\
\text { about new rice } \\
\text { information/technology. }\end{array}$ & 4.06 & $\begin{array}{l}\text { Moderately } \\
\text { Positive }\end{array}$ & 4.22 & Highly Positive \\
$\begin{array}{l}\text { When somebody is good at new } \\
\text { information/technology in rice } \\
\text { farming, I ask them to teach me } \\
\text { how to do it. }\end{array}$ & 4.40 & Highly Positive & 4.41 & Highly Positive \\
\hline
\end{tabular}

Similarly, both groups of cyber-village farmers had highly positive response to the statement, "I like to be informed of what my co-farmers know about the new rice knowledge/technology" ( $\mathrm{M}=4.23$ and $\mathrm{M}=4.27$ for LGU-managed and NGO-managed cyber-villagers, respectively). On the statement, "I ask from anyone about their practices when I need to learn about new rice information or technology," the LGU-managed farmers had moderately positive $(M=4.06)$ response, while the NGO-managed cybervillagers had highly positive $(M=4.22)$ response. Again, both groups had highly positive responses to the statement, "When somebody is good at new information or technology in rice farming, I ask them to teach me how to do it" ( $M=4.40$ and $M=4.41$ for LGUmanaged and LGU-managed cyber-villages, respectively). The overall ratings of both groups in terms of knowledge seeking were highly positive $(M=4.24$ and $M=4.30$ for LGU-managed and NGO-managed cyber-villages, respectively).

The farmers in the cyber-villages had a highly positive behavior in terms of seeking new rice technology from anybody whom they know were knowledgeable about it. They were eager to be informed about the new rice knowledge possessed by other farmers. When it comes to asking from anyone about his or her tacit knowledge, the NGO-managed farmers were more eager than their LGU-managed counterparts. The rice farmers from both camps were eager to learn from somebody who was good at new rice technology. Moreover, it appears that the cyber-village farmers still find more interest in receiving from others than in giving to others tacit and implicit knowledge on rice farming. The highly positive knowledge seeking behavior of the farmers implies that they place a high regard for acquiring tacit and explicit knowledge on rice farming from others.

Knowledge Donating Behavior. The LGU-managed cyber-villagers had a moderately positive $(M=4.09)$ response to the statement, "When I've learned something new about rice farming Information/technology, I tell my co-farmers about it." On the other hand, the NGO-managed cyber-villagers had a highly positive $(M=4.29)$ response to the same statement (Table 4).

The LGU-managed rice farmers had a highly positive response $(M=4.20)$ to the statement, "I share the information I have with my co-farmers" as compared to the NGOmanaged cyber-villagers who had a moderately positive response $(M=4.17)$ to the 
statement. Both the LGU-managed and NGO-managed cyber-villagers had moderately positive responses ( $M=4.17$ and $M=4.12$, respectively) to the statement, "I think it is important that my co-farmers know what I am doing in the rice farm. Similarly, both groups had moderately positive responses to the statement, "I regularly tell my co-farmers what I am doing in the rice farm" ( $M=4.06$ and $M=4.00$ for LGU-managed and NGOmanaged cyber-villagers, respectively). Both groups had moderately positive overall ratings ( $M=4.13$ for LGU-managed and $M=4.15$ for NGO-managed cyber-villagers) for knowledge donating behavior.

Table 4. Knowledge donating behavior of the rice farmers in the cyber-villages.

\begin{tabular}{|c|c|c|c|c|}
\hline \multirow[b]{2}{*}{ MEASURE } & \multicolumn{2}{|c|}{ LGU-MANAGED } & \multicolumn{2}{|c|}{ NGO-MANAGED } \\
\hline & $\begin{array}{l}\text { Mean } \\
\text { Score }\end{array}$ & $\begin{array}{l}\text { Qualitative } \\
\text { Description of } \\
\text { The Behavior }\end{array}$ & $\begin{array}{l}\text { Mean } \\
\text { Score }\end{array}$ & $\begin{array}{l}\text { Qualitative } \\
\text { Description of } \\
\text { The Behavior }\end{array}$ \\
\hline $\begin{array}{l}\text { When I've learned something } \\
\text { new about rice farming } \\
\text { information/ technology, I } \\
\text { tell my co-farmers about it. }\end{array}$ & 4.09 & Moderately Positive & 4.29 & Highly Positive \\
\hline $\begin{array}{l}\text { I share the information I } \\
\text { have with my co-farmers. }\end{array}$ & 4.20 & Highly Positive & 4.17 & Moderately Positive \\
\hline $\begin{array}{l}\text { I think it is important that my } \\
\text { co-farmers know what I am } \\
\text { doing in the rice farm. }\end{array}$ & 4.17 & Moderately Positive & 4.12 & Moderately Positive \\
\hline $\begin{array}{l}\text { I regularly tell my co-farmers } \\
\text { what I am doing in the rice } \\
\text { farm. }\end{array}$ & 4.06 & Moderately Positive & 4.00 & Moderately Positive \\
\hline Overall & 4.13 & Moderately Positive & 4.15 & Moderately Positive \\
\hline
\end{tabular}

The NGO-managed farmers had a more positive behavior than their LGU-managed counterparts when it comes to sharing to their co-farmers after they had learned something new about rice farming. On the other hand, the LGU-managed farmers had a more positive behavior than their NGO-managed counterparts when it comes to sharing of their knowledge or information to their co-farmers. Both groups had a moderately positive behavior in terms of the perceived importance of sharing to their co-farmers what they knew about rice farming. The farmers in the cyber-villages had moderately positive behavior when it comes to sharing to other farmers about what they are doing in their farms on a regular basis. In addition, the rice farmers in the cyber-villages were already agreeable to share their tacit and explicit knowledge.

Since the rice farmers in the cyber-villages appeared to be more knowledge seekers than knowledge donors, it indicates that they value knowledge on new rice technology (NRT) as an important resource but have some reservations on donating information to others. As they continue to be active in seeking more knowledge, their stock knowledge on NRT will accumulate, and if they will be motivated as knowledge donors, awareness about the NRT will readily spread within and outside the cyber-villages.

\section{Knowledge Sharing Ties}

The knowledge sharing ties of farmers within the cyber-villages were analyzed by looking at the network ties among the stakeholders. Network ties refer to the links or ties created through information exchange activities in the cyber-village communication network. The communication networks are assessed through various ties that connect all stakeholders across the cyber-villages.

As indicated in the social maps generated from UCINET 6 software (Borgatti et al., 2002), the ties or links between stakeholders are generated through their out-degree and in- 
degree links, as well as their reciprocated interaction. The out-degree refers to the outgoing links of each node or stakeholder while the in-degree is the incoming link that each node or stakeholder receives from others. In layman's parlance, the out-degree may refer to people who seek information from others while t0he in-degree may represent people who are being sought for or source of information.

As a whole, there was a similar trend in terms of number of links or ties and nodes or stakeholders of the LGU- and NGO-managed cyber-villages when it comes to knowledge seeking and knowledge donating ties. As indicated in their knowledge seeking network, the cyber-villagers appeared to have multiple sources of information about new rice technology.

In terms of network size, the cyber-villages became greater (having the higher number of nodes) in terms of knowledge donating ties. As implied in their knowledge donating ties, the 76-member network was transformed into a network of 159 stakeholders, indicating that the information about new rice technology acquired by the cyber-village members was imparted to another 83 non-members of the Cyber-Village Project.

To conceal the identity of the cyber-village farmers, letter codes and numbers were used. Letter codes also represented the barangay where the farmer came from. The letter codes used were as follows: for LGU-managed cyber-villages - BIN for Binulasan, GUM for Gumian and MAYP for Maypulot; for NGO-managed cyber-villages - ABI for Abiawin, ALI for Alitas, and BAL for Balobo.

Knowledge Seeking Ties. Knowledge seeking ties focused on the pattern of interaction among stakeholders in terms of "who acquires new rice knowledge from whom within the cyber-village" (out-degree) and "who are being sought for or source of new rice knowledge" (in-degree). During the interviews, the rice farmers were asked who among the cyber-village participants they would talk to if they want to acquire about new rice information or technology.

Figure 2 shows that there were 139 active ties or links in a network of 93 nodes or stakeholders in all the six barangays under the LGU-managed and NGO-managed cybervillages in terms of knowledge seeking. Among the active nodes or stakeholders, $28 \mathrm{had}$ indegree links composed of intermediaries (LGU1, LGU2, LGU3 and NGO1, LGUGN, PRICE and IRRI), co-farmers (ABI4, ALI15, BAL1, BAL6, BAL7, BIN6, BIN7, BIN14, GUM1, MAYP6, MAYP8 and MAYP10), and non-cyber-villagers (NAB1, NAL1, NBAL1, NBAL2, NBAL3, NBAL4, NMAY1, NMAY2 and NMIS1) who actually served as knowledge sources or knowledge faucets, as called by Monge and Contractor (2003). The common knowledge faucets on new rice technology in the network were LGU1, LGU3, and NGO1. In social networks, they are called bridges.

Results showed that there were two isolates and reciprocated interaction in the network.

Based on the most number of in-degree active links, NGO1, LGU1, LGU2, LGU3, ALI15, GUM1, and PRICE could be considered as central points or hubs across knowledge seeking network in the cyber-villages. It is interesting to note that not only the intermediaries but also the farmer-leaders are already serving as sources of new rice technology. As gleaned from Figure 2, ALI15 who is a farmer-leader in the NGO-managed cyber-village in Brgy. Alitas and GUM1 who is a farmer-leader in the LGU-managed cybervillage in Brgy. Gumian are already active sources of new rice technology. Also, there are potential cyber-villagers who could be trained to become prominent knowledge faucets including MAYP6, MAYP10, and MAYP8 in Brgy. Maypulot (LGU-managed), BIN5, BIN6, and BIN14 in Brgy. Binulasan (LGU-managed), BAL1, BAL6, and BAL7 in Brgy. Balobo (NGO-managed), and ABI4 in Bgry. Abiawin (NGO-managed) cyber-villages.

In general, the new rice knowledge in the cyber-villages are sourced out primarily from the intermediaries and a few farmer-leaders. Hence, under the Cyber-Village Project, it could be deduced that the new rice knowledge flows from IRRI to the intermediaries and some farmer-leaders who in turn share such knowledge to the members of the cyber- 
villages. The knowledge seeking ties in the cyber-villages could be described as "sink and faucet" relationship (Monge \& Contractor, 2003). The word "sink" refers to a person who only receives information from other someone called as "faucet" or the one who provides or shares information. This is supported by the fact that there was no mutual relationship or reciprocated interaction within the network. One of the reasons for the absence of reciprocated interaction in the network is the fact that most stakeholders perceive themselves as less knowledgeable than others. The intermediaries were perceived as more knowledgeable by the rice farmers in terms of new rice knowledge and practices, and this was exemplified by the high level of trust they ascribed to the cyber-village intermediaries. Moreover, the heavy reliance of the cyber-villagers on the know-how and expertise of the intermediaries is a good indicator that the knowledge products that would be shared to other farmers in the villages are coming from reliable sources.

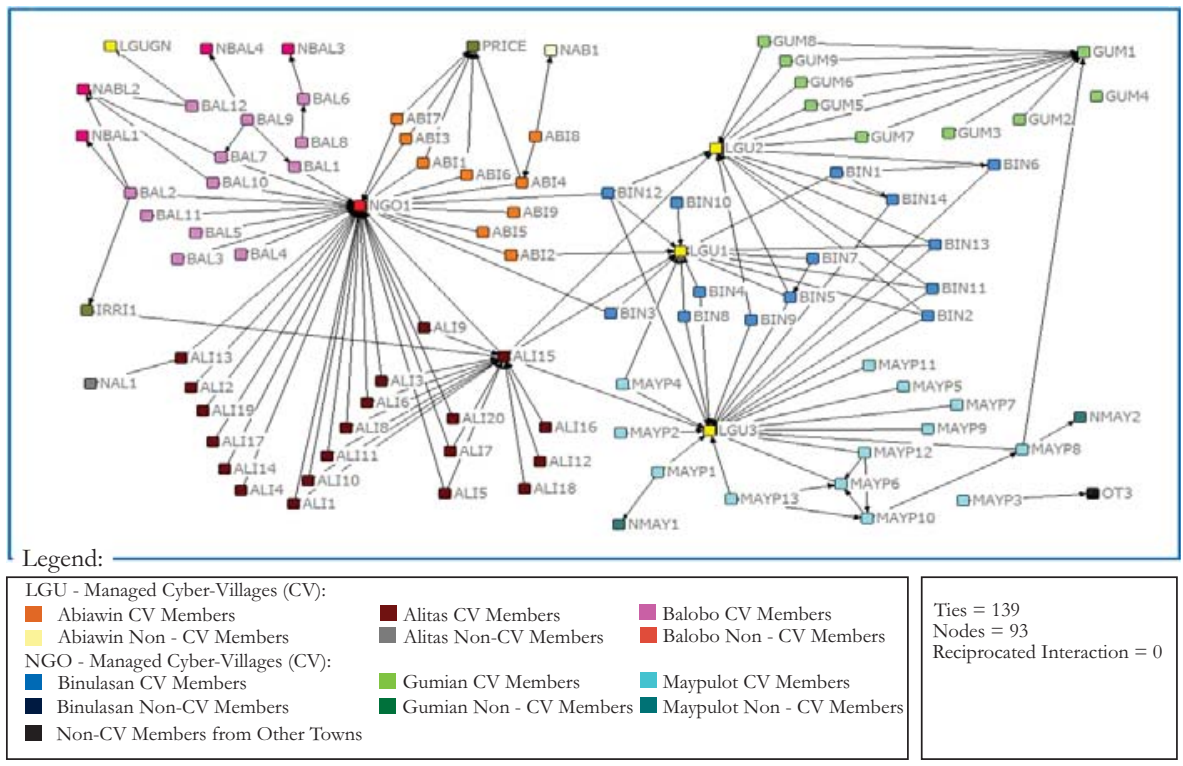

Figure 2. Knowledge seeking ties of all barangays under the LGU-managed and NGO-managed cyber-villages.

Knowledge Donating Ties. Building on "who gives new rice knowledge to whom within the cyber-village" (out-degree) and "who are the recipients of new rice knowledge" (indegree), knowledge donating ties are determined based on the number of incoming and outgoing links that each stakeholder has in terms of sharing new rice knowledge/technology. To generate the knowledge donating ties, the farmers were queried on whom they share it with if they have learned something about new rice technology.

The whole knowledge donating network of the cyber-villages in Infanta, Quezon had 142 active ties or links and 159 nodes or stakeholders. In other words, the LGU-managed cyber-villages composed of 76 members were turned into an 80-noded network in terms of knowledge donating (Figure 3).

Aside from directly sharing the new rice knowledge/technology to the non-members of the cyber-village, a number of farmer-members first relayed the new rice technology to their co-farmer-members and then shared such information to the non-members of the cyber-village. This was evident in the 24 cyber-villagers with in-degree ties coming from five barangays (ABI2, ALI4, ALI6, ALI9, ALI13, ALI15, BAL1, BAL3, BAL4, BAL5, BAL6, BAL7, BAL8, BAL9, BAL11, BAL12, BIN1, BIN7, BIN8, BIN12, MAYP1, MAYP2, MAYP3, and MAYP6). There were three reciprocated interactions all coming 
from the NGO-managed cyber-villages (ALI11 and ALI12; BAL5 and BAL; and BAL6 and BAL11) that existed in the network. Two isolates (BIN10 and GUM4) coming from LGU-managed cyber-villages were found in the network. Also, each of the six cybervillages were mutually exclusive, being related such that each excludes or precludes the other, and there was no bridge or liaison that had interaction across all networks in terms of knowledge donating.
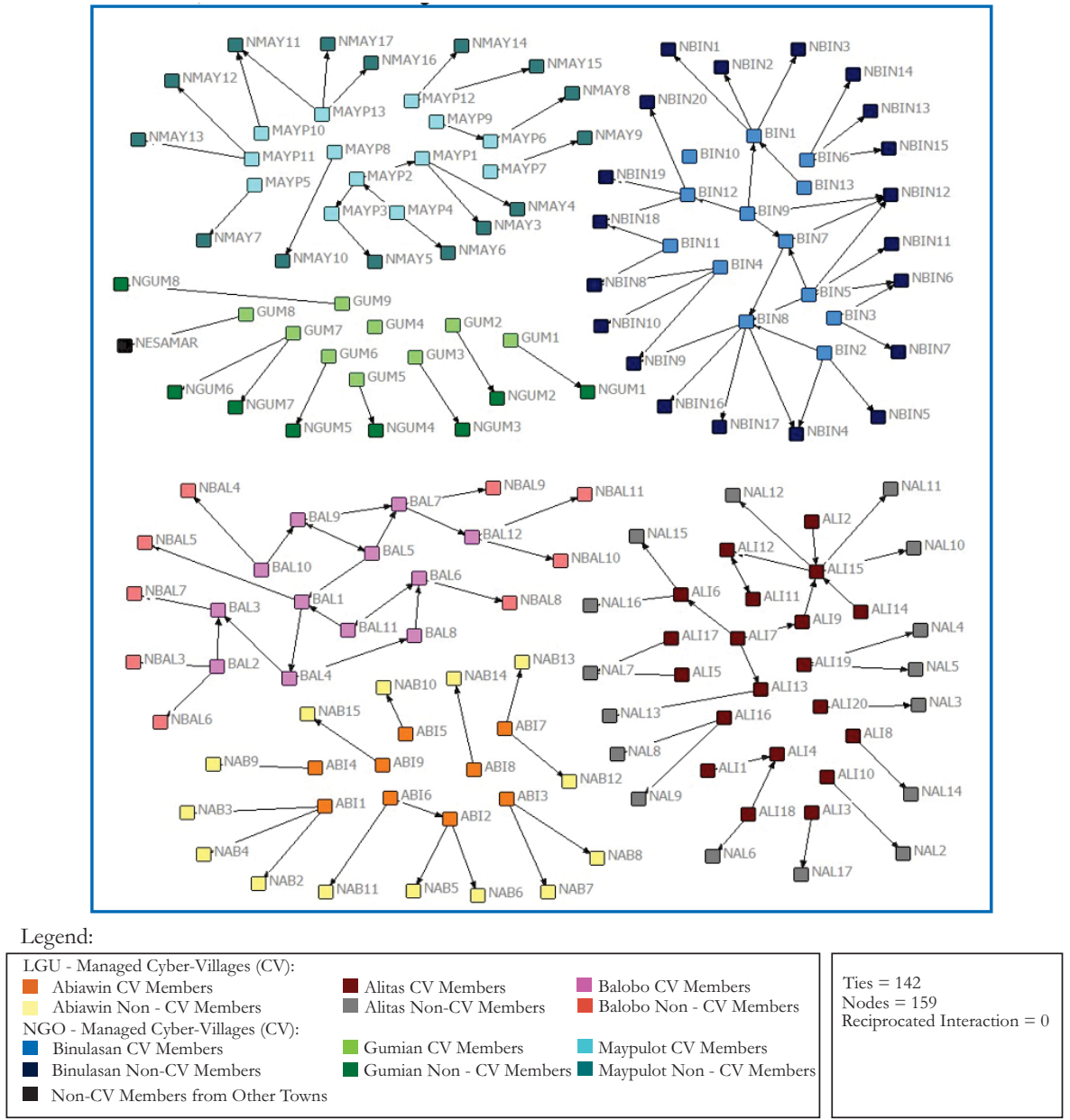

Figure 3. Knowledge donating ties of all barangays under the LGU-managed and NGO-managed cyber-villages.

Taken as a whole, the 76 members of the Cyber-Village Project who obtained new rice knowledge/technology were able to share such relevant information to 83 others who were not members of the cyber-village. Unlike their knowledge seeking ties, the knowledge donating behavior in the cyber-villages could no longer be described as "sink and faucet" relationship. Hence, in the case of knowledge donating, there are mutual relationships or reciprocated interactions emerging among the cyber-village members which could be translated into a dynamic knowledge sharing within and outside the cyber-village spheres.

\section{CONCLUSION}

In terms of knowledge sharing behavior, the cyber-village farmers are more of a 
knowledge seeker than a knowledge donor, implying the necessity of the farmers to be educated about new rice knowledge and to be honed in terms of effective communicative skills. The latent networks are predominantly star and linear chain, characterized by sparse central hubs and non-reciprocated ties. The central actors are limited to the intermediaries, farmer-leaders, and emerging farmer-consultants.

\section{ACKNOWLEDGMENT}

The Philippine Commission on Higher Education (CHED) through its Faculty Development Program Phase 2 (FDP-2) provided financial assistance for the conduct of this study. Special thanks also go to the International Rice Research Institute (IRRI) for the additional financial and logistical support.

ALIEI, M., B. ASHRAFI and S. AGHAYAN. 2011. Studying relationships between organizational citizenship behaviour and knowledge sharing (Case study knowledgebased organizations). Interdisciplinary Journal of Contemporary Research in Business 3(3): 341-348

DALKIR, K. 2003. Knowledge Management in Theory and Practice. Butterworth Heinemann: Elsevier

DE VRIES, R. and B. VAN DEN HOOF. 2006. Explaining knowledge sharing: The role of team communication styles, job satisfaction, and performance beliefs. Communication Research 33(2): 115-135

GALIE, A., B. HACK, N. MANNING-THOMAS, A. PAPE-CHRISTIANSEN, S. GRANDO and S. CECCARELLI. 2009. Evaluating knowledge sharing in research: the International Farmers' Conference organized at ICARDA. Knowledge Management for Development Journal 5(2): 108-126

HEYRADI, A.R., H. ARMESH, S. BEHJATIE and M. MANAFI. 2011. Determinant of incentive factors in knowledge sharing. Interdisciplinary Journal of Contemporary Research in Business 3(1): 83-95

KUHNE, B., E. LAMBRECHT and X. GELLYNCK. 2011. Network types and their importance for knowledge exchange and innovation in the agri- and horticultural sector. A paper presented during the International Food and Agribusiness Management Association 21 ${ }^{\text {st }}$ Annual World Symposium on June 20-23, 2011, Frankfurt, Germany.

LAPITAN, J. and N. MAGOR. 2009. Proposal: Enhancing knowledge exchange and decision-making among rice stakeholders through the development and promotion of location-specific rice knowledge products and delivery systems. International Rice Research Institute, Los Baños, Laguna, Philippines

LAPITAN, J., F. PALIS, and N. MAGOR. 2012. Enhancing Knowledge Exchange and Decision-Making Among Rice Stakeholders Through the Development and Promotion of Location-Specific Rice Knowledge Products and Delivery Systems: Year 1 Report. International Rice Research Institute, Los Baños, Laguna, Philippines

LIU, P., B. RAAHEMI and M. BENYOUCEF. 2011. Knowledge sharing in dynamic virtual enterprises: A socio-technological perspective. Knowledge-Based Systems 24: 427443

MONAHAN, G. 2000. Management Decision Making. Cambridge: Cambridge University Press

MONGE, P.R. AND N. CONTRACTOR. 2003. Theories of Communication Networks. New York: Oxford University Press

REASON, J. 1990. Human Error. Ashgate. ISBN 1840141042

TRIANTAPHYLLOU, E. 2000. Multi-Criteria Decision Making: A Comparative Study. Dordrecht, The Netherlands: Kluwer Academic Publishers (now Springer) 
VAN DEN HOOFF, B., and M. HUYSMAN. 2009. Managing knowledge sharing: Emergent and engineering approaches. Information and Management 46: 1-8

WANG, S. and R.A. NOE. 2010. Knowledge sharing: A review and directions for future research. Human Resource Management Review 20:115 